\title{
HFE H63D mutation frequency shows an increase in Turkish women with breast cancer
}

\author{
Aysen Gunel-Ozcan*1, Sibel Alyllmaz-Bekmez¹, Emine Nilufer Guler ${ }^{2}$ and \\ Dicle $\mathrm{Guc}^{3}$
}

Address: ${ }^{1}$ Kirikkale University School of Medicine, Department of Medical Biology and Genetics, Kirikkale, Turkey, ${ }^{2}$ Hacettepe University, Oncology Institute, Medical Oncology Department, Ankara, Turkey and ${ }^{3}$ Hacettepe University, Oncology Institute, Basic Oncology Department, Ankara, Turkey

Email: Aysen Gunel-Ozcan* - agozcan@yahoo.com; Sibel Alyllmaz-Bekmez - alyilmazs@mynet.com; Emine Nilufer Guler - nguler@hacettepe.edu.tr; Dicle Guc - dguc@hacettepe.edu.tr

* Corresponding author

Published: 19 February 2006

BMC Cancer 2006, 6:37 doi:10.1186/147|-2407-6-37
Received: 14 October 2005

Accepted: 19 February 2006

This article is available from: http://www.biomedcentral.com/I47I-2407/6/37

(C) 2006 Gunel-Ozcan et al; licensee BioMed Central Ltd.

This is an Open Access article distributed under the terms of the Creative Commons Attribution License (http://creativecommons.org/licenses/by/2.0), which permits unrestricted use, distribution, and reproduction in any medium, provided the original work is properly cited.

\begin{abstract}
Background: The hereditary hemochromatosis gene HFE plays a pivotal role in iron homeostasis. The association between cancer and HFE hetero- or homozygosity has previously been shown including hepatocellular and nonhepatocellular malignancies. This study was performed to compare frequencies of HFE C282Y and H63D variants in Turkish women with breast cancer and healthy controls.
\end{abstract}

Methods: Archived DNA samples of Hacettepe University Oncology Institute were used in this study. The HFE gene was investigated by PCR-RFLP.

Results: All subjects studied were free from C282Y mutation. Thirty-nine patients had H63D mutation and were all heterozygous. H63D allele frequency was $22.2 \%(39 / 176)$ in the breast cancer patients, and $14 \%(28 / 200)$ in the healthy volunteers. Statistical analysis of cases with HFE H63D phenotype showed significant difference between breast cancer and healthy volunteers $(P=$ 0.02).

Conclusion: Our results suggest that HFE H63D mutation frequencies were increased in the breast cancer patients in comparison to those in the general population. Also, odds ratios (odds ratio $=2.05$ ) computed in this study suggest that $\mathrm{H} 63 \mathrm{D}$ has a positive association with breast cancer.

\section{Background}

The hereditary hemochromatosis gene HFE (6p21.3) 4 $\mathrm{Mb}$ telomeric to the HLA-A locus, and its product has a structure similar to MHC class I molecules [1]. It has a critical role in iron homeostasis. The total number of HFE variants detected to date is at least 37, of which 19 are missense [2]. Two mutations, C282Y (the substitution of tyro- sine for cysteine at position 282) and H63D (the substitution of aspartate for histidine at position 63), are particularly frequent among patients with hereditary hemochromatosis [1] that is characterized by hepatic fibrosis and cirrhosis, diabetes mellitus, skin pigmentation, hypogonadism, arthropathy and cardiomyopathy as a result of excessive iron absorption from the gut and sub- 


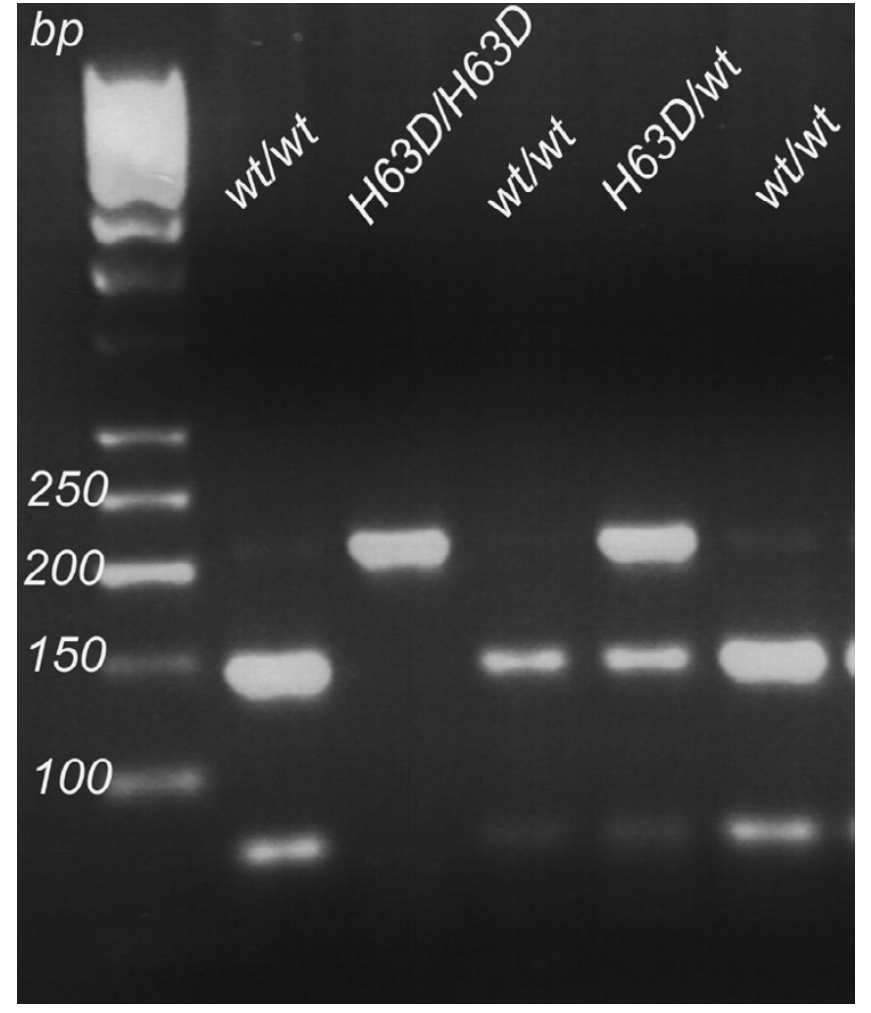

Figure I

Determination of H63D mutation of the HFE gene by restriction enzyme analysis. Molecular weight marker (MW) sizes are shown on the first lane.

sequent accumulation of iron in organs. HFE protein forms a stable complex with transferrin receptor (TFR), thereby reducing its affinity for transferrin (TF) by approximately ten fold [3]. TF is the major iron transport protein in blood and TFR facilitates the uptake of ironbound transferrin. $\mathrm{C} 282 \mathrm{Y}$ mutation prevents the association of the mutant HFE protein with TFR because of the lack of cell surface expression [4]. As a result, increased affinity of the uncomplexed TFR for TF causes higher iron absorption. The significance of the H63D mutation on the HFE gene was at first controversial [1,3]. Subsequent studies suggested a functional role for H63D mutation $[3,5,6]$. The H63D variant of the HFE protein does reach the cell surface and forms a stable complex with TFR but fails to control high TFR affinity for TF [7].

HFE mutation frequencies show marked geographical differences throughout the world. Most Caucasian patients of Northwestern European ancestry with hereditary hemochromatosis are homozygous for C282Y $[8,9]$. Compound heterozygotes for the C282Y and H63D mutations expressing hemochromatosis are also observed, but with less penetrance than C282Y homozygotes $[6,8]$. Besides hepatocellular carcinoma $[10,11]$

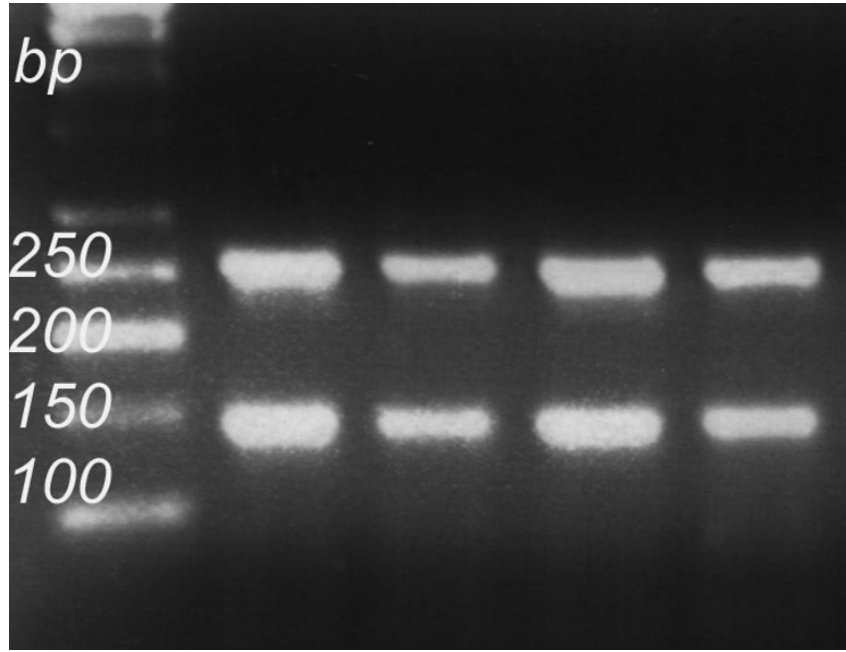

Figure 2

Determination of C282Y mutation of the HFE gene by restriction enzyme analysis. Neither homozygote nor heterozygote C282Y mutations were found in patients or in healthy controls.

common malignancies, including hematological [12-14], colorectal cancer [15-17], and breast cancer [15,18] show risk associations with $\mathrm{C} 282 \mathrm{Y}$. However, there are contradictious studies showing no association between the HFE mutations and cancer risk [19-22].

One possible mechanism for the association might be the load of reactive free iron molecules which may cause DNA damage $[23,24]$, which may suppress the host defense cells and induce proliferation [25,26], and which may convert nitric oxide from a proapoptotic to an antiapoptotic molecule [27].

The current report outlines our analysis of $\mathrm{C} 282 \mathrm{Y}$ and H63D mutations in Turkish breast cancer patients and control subjects from the same geographical area.

\section{Methods}

\section{Patients and Controls}

In this study, we used 88 archived DNA samples, which had been isolated from blood samples of patients with breast cancer diagnosed at Hacettepe University Oncology Institute Department of Medical Oncology in Turkey over the last ten years. The mean age at diagnosis for the breast cancer patients was $41 \mathrm{yr}$ (range, 21-75). The population controls consisted of 100 DNA samples from voluntary and healthy women who lived in Ankara, located at central Turkey. The mean age of the controls was $33 \mathrm{yr}$ (range, 21-70). This study has been approved by the Hacettepe University Ethics Committee. 
Table I: HFE mutations with nucleotide changes and their positions within HFE

\begin{tabular}{|c|c|c|c|}
\hline Mutation & Nucleotide change & $\begin{array}{l}\text { Position relative to initiating } \\
\text { ATG [GenBank: } \underline{\cup 63 \mid 9]}\end{array}$ & Position in HFE \\
\hline $\mathrm{C} 282 \mathrm{Y}$ & $\mathrm{G} \rightarrow \mathrm{A}$ & 5473 & Exon 4 \\
\hline H63D & $\mathrm{C} \rightarrow \mathrm{G}$ & 3513 & Exon 2 \\
\hline
\end{tabular}

\section{PCR-RFLP}

PCR amplification and electrophoresis were performed by using the standard procedures described previously $[1,28]$. The following general HFE primers were used at annealing temperature of $58^{\circ} \mathrm{C}$ and $57.4^{\circ} \mathrm{C}$ for analysis of C282Y and H63D mutations:

\section{C282Y-Forward; 5'-TGGCAAGGGTAAACAGATCC-3',}

\section{C282Y-Reverse; 5'-CTCAGGCACTCCTCTCAACC-3',}

H63D-Forward; 5'-ACATGGTTAAGGCCTGTTGC-3',

\section{H63D-Reverse; 5'-GCCACATCTGGCTTGAAATT-3'.}

The amplified fragments were digested with RsaI for the C282Y and $\mathrm{Bcl}$ I for the H63D mutations. Upon digestion with RsaI, the 387 bp PCR product of $\mathrm{C} 282 \mathrm{Y}$ region shows two fragments of $247 \mathrm{bp}$ and $140 \mathrm{bp}$ in normal DNA and two additional fragments of $111 \mathrm{bp}$ and $29 \mathrm{bp}$ in mutant DNA. The 294 bp H63D region PCR product digested with $\mathrm{Bcl}$ I generates fragments of $138 \mathrm{bp}, 70 \mathrm{bp}$ in normal DNA and 208 bp in mutant DNA [28]. PCR digests were analyzed on $2.5 \%$ agarose gels (Figure 1 and 2). The relative positions of the mutations analyzed in the present study are given in Table 1.

\section{Statistical analyses}

Frequencies of the HFE alleles were calculated by gene counting. Hardy-Weinberg equilibrium was tested before proceeding to the analysis. Statistical analysis of mutation prevalence in case and control groups was performed by using two-tailed Fisher's exact test. The proportions of patients with breast cancer and healthy volunteers who carried at least one mutant allele are presented with 95\% confidence intervals (CIs) and Odds Ratio (OR). Analyses were performed by using Instat V2.02 (GraphPad Inc USA) statistical software package. In general group comparisons $P$ value $<0.05$ was accepted as statistically significant whereas in subgroup analysis after making Bonferroni adjustment $P$ value $<0.0125$ value was accepted as statistically significant.

\section{Results}

According to the birth of place thirty-eight percent of the entire cases was from Central Turkey, twenty-eight percent was from South and West (Mediterranean region), twenty percent was from East, and fifteen percent was from North (Black Sea region). Information about cancer type and stages were available for 52 patients, and ninety-three percent of them had infiltrative ductal carcinoma and ninetyfour percent of the women had limited-stage (stages I-III), 3 women $(6 \%)$ had distant metastases at diagnosis.

There was no significant deviation from Hardy-Weinberg equilibrium in the distribution of genotypes in the control group. In the control group of 100 women, HFE H63D allele frequency was 14\%, and the frequency of HFE H63D-homozygosity was 1\%. Overall allele frequency for breast cancer group of 88 women (71 sporadic and 17 familial), for HFE H63D was 22.2\% whereas there were no HFE H63D-homozygotes in the group. Statistical analysis of cases with HFE H63D phenotype showed significant difference between breast cancer and healthy volunteers $(P=0.02, \mathrm{OR}=2.05,95 \% \mathrm{CI}=1.12$ to 3.75$)$ whereas there was no significant difference between either

Table 2: Characteristics of breast cancer patients

\begin{tabular}{lcc}
\hline Variable & & HFE genotype \\
\cline { 2 - 3 } & H63D allele & Wt/Wt \\
\hline Mean age at diagnosis in years (range) & $42(32-75)$ & $40(26-62)$ \\
Premenopausal at diagnosis & $\mathrm{N}=22$ & $\mathrm{~N}=35$ \\
Familial & $\mathrm{N}=8$ & $\mathrm{~N}=9$ \\
Early onset & $\mathrm{N}=12$ & $\mathrm{~N}=22$ \\
Sporadic & $\mathrm{N}=31$ & $\mathrm{~N}=40$ \\
\hline
\end{tabular}

$\Psi$ Heterozygous patients for $\mathrm{H} 63 \mathrm{D}$ allele.

$\xi W t / W t$, homozygous wild-type.

* Patients diagnosed at younger than 40 years. 
Table 3: Statistical analysis of cases with H63D mutation. Analysis between Total breast cancer patients and Healthy controls, Sporadic breast cancer patients and Healthy controls, Familial breast cancer patients and Healthy controls, Sporadic breast cancer and Familial breast cancer patients, Premenopausal and Postmenopausal breast cancer patients are shown. One healthy volunteer was homozygous for the mutation; all other subjects listed here were heterozygous. All the subjects studied were free from C282Y mutation.

\begin{tabular}{|c|c|c|c|c|}
\hline & Cases with H63D mutation & $\begin{array}{l}P \text { value } \\
\text { (two-sided) }\end{array}$ & $\begin{array}{l}\text { Odds ratio } \\
\text { (OR) }\end{array}$ & $\begin{array}{l}\% 95 \text { Confidence Interval-Cl- } \\
\text { (using the approximation of Woolf) }\end{array}$ \\
\hline $\begin{array}{l}\text { Total breast cancer patients: Healthy } \\
\text { controls }\end{array}$ & 39/88: $28 / 100$ & 0.02 & 2.05 & I. 12 to 3.75 \\
\hline $\begin{array}{l}\text { Sporadic breast cancer patients: Healthy } \\
\text { controls }\end{array}$ & $3|/ 7|: 28 / 100$ & 0.05 & 2 & 1.05 to 3.78 \\
\hline $\begin{array}{l}\text { Familial breast cancer patients: Healthy } \\
\text { controls }\end{array}$ & 8/17: 28/100 & 0.15 & 2.29 & 0.80 to 6.52 \\
\hline $\begin{array}{l}\text { Sporadic breast cancer patients: Familial } \\
\text { breast cancer patients }\end{array}$ & $3|/ 7|: 8 / 17$ & 1 & 1.15 & 0.4 to 3.32 \\
\hline $\begin{array}{l}\text { Premenopausal breast cancer patients: } \\
\text { Post menopausal breast cancer patients }\end{array}$ & 22/57: $5 / 7$ & 0.12 & 0.25 & 0.04 to $1.4 \mathrm{I}$ \\
\hline
\end{tabular}

familial breast cancer and healthy volunteers or familial and sporadic breast cancer groups (Table 3). Subgroup analysis showed that the difference between the cases and control groups is based on the sporadic cases $(\mathrm{P}=0.0001$, $\mathrm{OR}=3.13,95 \% \mathrm{CI}=1.65$ to 5.94$)$. Information for the pre- and post-menopausal status was available for only 64 patients. Statistical analysis of cases with HFE H63D mutation among these patients showed no significant differences between premenopasual and postmenopausal breast cancer (Table 3). Characteristics of breast cancer patients with respect to $H 63 D$ allele are summarized in Table 2 . There were also no statistically significant differences between breast cancer patients with and without the H63D allele with respect to age or heredity. All subjects studied were free from C282Y mutation.

\section{Discussion}

As expected from previous population studies [29-31] we did not find any C282Y mutation among the Turkish women who participated in this study. The results of this case-control study showed that H63D was more common in breast cancer patients. Because endogenous estrogens are more closely related to postmenopausal breast cancer and iron might have a role at redox-cycling estrogen metabolites to produce hydroxyl radicals $[32,33]$, we compared premenopasual and postmenopausal breast cancer for the HFE H63D mutation. Since significant iron loss stops with menopause, an increase in HFE-associated cancer risk might also be possible. Contrary, there was no statistically significant difference between these groups $(P$ $=0.12$ ).

To the best of our knowledge, this is the second study that shows a significant association between female breast cancer and HFE-H63D although a subgroup analysis in a general cancer association study also revealed a nonsignificantly increased odds ratio for H63D carriers ( $\mathrm{n}=$
$18, \mathrm{OR}=2.0, P=0.14)$ in breast cancer [12]. A recent article, making the same comparisons of H63D mutation frequency between Russian women with breast cancer and controls, found age to be an important confounder of the association, wherein a positive association of H63D with breast cancer was only found among women over 57 years old [34]. Because of the insufficient number of the women over 45 years old in our study (Control $\mathrm{N}=5$, Cases $\mathrm{N}=22$ ), the estimation could be made in wide range which might cause unreliable interpretations. Therefore, age-specific analysis was not performed in this study. Another recent study showed no association between male breast cancer and H63D [35]. Although the lack of gender difference shown in association between HFE genotypes and medical conditions related to iron overload other than cancer [36], this variability in women with H63D mutations with respect to cancer risk could be the influence of potential modifier factors for breast cancer. The only other cancer association with H63D is with malignant gliomas [37]. If replicated elsewhere, further studies can be designed to distinguish between mechanistic possibilities. Our study had some limitations. We were unable to study the effect of H63D on serum iron parameters or gene and environment interactions, as we did not have stored serum samples from patients nor dietary or medication (oral contraceptives, etc) history. Ideally, a sample larger than ours should be studied in a genetic association study to rule out the chance factor. Not only is the study small, but when a small number of multiple comparisons are made, the power of the study is further diminished. When Bonferroni correction were made the comparison between the cases and controls in this study was no longer significant ( $p=0.02$ vs. $a=0.0125$ ).

We compared the data on H63D frequencies from other population studies in Turkey. Our control frequency from age-matched females is in general agreement with other 
results which are $13.6 \%, 11.6 \%$ respectively $[29,30]$. The only exception is the study by Simsek et al., which reported a higher H63D mutation frequency (24.9\%) from predominantly male blood donors [31]. A larger control group consisting of truly population-based females would have yielded a more robust estimate of the frequency if we had had the resources to achieve that.

The role of H63D in iron homeostasis is well established. Although an animal study unambiguously showed an effect of H63D mutation on hemochromatosis development [38], a human twin study established the influence of H63D on transferrin saturation levels [39]. Significant increases in both transferrin saturation and serum ferritin levels in H63D heterozygotes versus HFE wild type controls have also been demonstrated in large population studies [40-42]. HFE H63D mutation is very variable worldwide. The carrier frequency of the H63D mutation is $21.6 \%$ in Europe, 5.4\% in Africa/Middle-East, 2.8\% Asia and $22.8 \%$ in America [9]. One possibility is that H63D association with breast cancer might have been a selection of a specific subgroup among Turkish population. Turkey has a very heterogeneous population whose ancestries are from Anatolia (east Mediterranean region), Middle East and Central Asia. Related or unrelated susceptibility gene mutations, especially the ones which show ethnic dependence may both arise at higher frequencies in a specific subgroup of the mix-population. However, being a reference center Hacettepe Oncology Institute has the potential to comprise patients from different regions of Turkey and therefore, it is less likely that a specific subgroup of the population has been selected for this study.

Despite a large physical distance, the genetic distance between HFE and the telomeric end of the HLA complex is less than $1 \mathrm{cM}$. This results in linkage disequilibrium between H63D and HLA-A29 [43,44]. One alternative explanation is therefore confounding by locus, e.g., an HLA association may have appeared as H63D association in our study due to linkage disequilibrium. HLA loci have been studied in breast cancer and several associations have been reported but most importantly a recent large family study mapped a breast cancer susceptibility locus towards the telomeric end of the HLA complex [45]. The region between HFE and the HLA complex has another feature that may be relevant in the mechanism of an association with H63D. A significant correlation with CD8+ Tcell numbers, but not with CD4+ T-cell numbers, in subjects carrying both HLA-A29 and H63D or both HLAA*01 and H63D mutation has been reported $[44,46]$. Thus, the H63D association may be a reflection of an immune response gene association in the region between HFE and HLA. Further large studies on HFE association with breast cancer susceptibility in populations lacking the $\mathrm{C} 282 \mathrm{Y}$ mutation may need to include markers from
HLA loci, loci between the HLA complex and HFE and other variants of the HFE gene for more meaningful results than our preliminary study has shown.

\section{Conclusion}

We did not find any $\mathrm{C} 282 \mathrm{Y}$ mutation among the Turkish women who participated in this study. The results of this case-control study show that H63D has a positive association with breast cancer. However, when a small number of multiple comparisons are made, the power of the study is diminished. Ideally, a sample larger than ours should be studied in a genetic association study to rule out the chance factor.

\section{Competing interests}

The author(s) declare that they have no competing interests.

\section{Authors' contributions}

AGO designed the study, carried out the molecular genetic (PCR-RFLP) studies, performed the statistical analysis and drafted the manuscript. SAB participated in the PCR-RFLP studies. ENG is the medical oncologist who diagnosed breast cancer patients and gave the related information. DG provided DNA samples of the patients and control group and helped to draft the manuscript. All authors read and approved the final manuscript.

\section{Acknowledgements}

This work was supported in part by Kirikkale University Research Found (KÜ AF 02/08.01.04) and Eczacibasi Scientific Research and Award Found. We thank the cancer patients and healthy volunteers who made this analysis possible. We also thank Professor M. Oguz Guc and Handan Camdeviren-Ankarali for reviewing the statistical analysis.

\section{References}

I. Feder JN, Gnirke A, Thomas W, Tsuchihashi Z, Ruddy DA, Basava A, Dormishian F, Domingo R Jr, Ellis MC, Fullan A, Hinton LM, Jones NL, Kimmel BE, Kronmal GS, Lauer P, Lee VK, Loeb DB, Mapa FA, McClelland E, Meyer NC, Mintier GA, Moeller N, Moore T, Morikang E, Prass CE, Quintana L, Starnes SM, Schatzman RC, Brunke KJ, Drayna DT, Risch NJ, Bacon BR, Wolff RK: A novel MHC class Ilike gene is mutated in patients with hereditary haemochromatosis. Nat Genet 1996, I3:399-408.

2. Beutler L, Beutler E: Hematologically important mutations: iron storage diseases. Blood Cells Mol Dis 2004, 33:40-44.

3. Feder JN, Penny DM, Irrinki A, Lee VK, Lebron JA, Watson N, Tsuchihashi Z, Sigal E, Bjorkman PJ, Schatzman RC: The hemochromatosis gene product complexes with the transferrin receptor and lowers its affinity for ligand binding. Proc Natl Acad Sci USA 1998, 95: | 472-1477.

4. Feder JN, Tsuchihashi Z, Irrinki A, Lee VK, Mapa FA, Morikang E, Prass CE, Starnes SM, Wolff RK, Parkkila S, Sly WS, Schatzman RC: The hemochromatosis founder mutation in HLA-H disrupts $b_{2}$-microglobulin interaction and cell surface expression. J Biol Chem 1997, 272: I4025-14028.

5. Beutler $E$ : The significance of the 187G (H63D) mutation in hemochromatosis. Am J Hum Genet 1997, 61:762-764.

6. Fairbanks VF, Brandhagen DJ, Thibodeau SN, Snow K, Wollan PC: $\mathrm{H63D}$ is an haemochromatosis associated allele. Gut 1998, 43:441-442.

7. Waheed A, Parkkila S, Zhou XY, Tomatsu S, Tsuchihashi Z, Feder JN, Schatzman RC, Britton RS, Bacon BR, Sly WS: Hereditary hemochromatosis: effects of C282Y and H63D mutations on asso- 
ciation with beta2-microglobulin, intracellular processing and cell surface expression of the HFE protein in COS-7 cells. Proc Natl Acad Sci USA 1997, 94: I2384-I 2389

8. Beutler E, Gelbart T, West C, Lee P, Adams M, Blackstone R, Pockros P, Kosty M, Venditti CP, Phatak PD, Seese NK, Chorney KA, Ten Elshof AE, Gerhard GS, Chorney M: Mutation analysis in hereditary hemochromatosis. Blood Cells Mol Dis 1996, 22: I87-194.

9. Hanson EH, Imperatore G, Burke W: HFE gene and Hereditary Hemochromatosis: a HuGE review. Human Genome Epidemiology. Am J Epidemiol 200I, 154:193-206.

10. Hellerbrand C, Poppl A, Hartmann A, Scholmerich J, Lock G: HFE C282Y heterozygosity in hepatocellular carcinoma: evidence for an increased prevalence. Clin Gastroenterol Hepatol 2003, I:279-284.

II. Cauza E, Peck-Radosavljevic M, Ulrich-Pur H, Datz C, Gschwantler M, Schoniger-Hekele M, Hackl F, Polli C, Rasoul-Rockenschaub S, Muller C, Wrba F, Gangl A, Ferenci P: Mutations of the HFE gene in patients with hepatocellular carcinoma. Am J Gastroenterol 2003, 98:442-447.

12. Barton JC, Bertoli LF, Acton RT: HFE C282Y and H63D in adults with malignancies in a community medical oncology practice. BMC Cancer 2004, 4:6.

13. Dorak MT, Burnett AK, Worwood M, Sproul AM, Gibson BE: The C282Y mutation of HFE is another male-specific risk factor for childhood acute lymphoblastic leukemia. Blood 1999 94:3957-3958.

14. Dorak MT, Burnett AK, Worwood M: HFE gene mutations in susceptibility to childhood leukemia: HuGE review. Genet Med 2005, 7:159-167.

15. Beckman LE, Van Landeghem GF, Sikström C, Wahlin A, Markevarn B, Hallmans G, Lenner P, Athlin L, Stenling R, Beckman L: Interaction between haemochromatosis and transferrin receptor genes in different neoplastic disorders. Carcinogenesis 1999 , 20: $|23|-\mid 233$

16. Altes A, Gimferrer E, Capella G, Barcelo MJ, Baiget M: Colorectal cancer and HFE gene mutations. Haematologica 1999 84:479-480.

17. Robinson JP, Johnson VL, Rogers PA, Houlston RS, Maher ER, Bishop DT, Evans DG, Thomas HJ, Tomlinson IP, Silver AR: Evidence for association between compound heterozygosity for germ line mutations in the hemochromatosis (HFE) gene and increased risk colorectal cancer. Cancer Epidemiol Biomarkers Prev 2005, I 4: | 460-| 463 .

18. Kallianpur AR, Hall LD, Yadav M, Christman BW, Dittus RS, Haines IL, Parl FF, Summar ML: Increased Prevalence of the HFE C282Y Hemochromatosis Allele in Women with Breast Cancer. Cancer Epidemiol Biomarkers Prev 2004, 1 3:205-2 I2.

19. Hannuksela J, Savolainen ER, Koistinen P, Parkkila S: Prevalence of HFE genotypes, C282Y and H63D, in patients with hematologic disorders. Haematologica 2002, 87: $131-135$.

20. van der $A D L$, van der Hel O, Roest M, van der Shouw YT, van Gils $\mathrm{CH}$, Marx JJ, van Noord PA, Peeters PH: Heterozygosity for the Cys282Tyr mutation in the HFE gene and the risk of colorectal cancer (Netherlands). Cancer Causes Control 2003, 1 4:54I-545.

21. Dorak MT, Burnett AK, Worwood M: Hemochromatosis gene in leukemia and lymphoma. Leuk Lymphoma 2002, 43:467-477.

22. Abraham BK, Justenhoven C, Pesch B, Harth V, Weirich G, Baisch C Rabstein S, Ko YD, Bruning T, Fischer HP, Haas S, Brod S, Oberkanins C, Hamann U, Brauch H, GENICA Network: Investigation of genetic variants of genes of the hemochromatosis pathway and their role in breast cancer. Cancer Epidemiol Biomarkers Prev 2005, I 4: I I02-II 07

23. Nunoshiba T, Obata F, Boss AC, Oikawa S, Mori T, Kawanishi S, Yamamoto K: Role of iron and superoxide for generation of hydroxyl radical, oxidative DNA lesions, and mutagenesis in Escherichia coli. J Biol Chem 1999, 274:34832-34837.

24. Sarkar B: Metal replacement in DNA-binding zinc finger proteins and its relevance to mutagenicity and carcinogenicity through free radical generation. Nutrition 1995, I I:646-649.

25. de Sousa M: Immune cell functions in iron overload. Clin Exp Immunol 1989, 75: I-6.

26. Green R, Esparza I, Schreiber R: Iron inhibits the non-specific tumoricidal activity of macrophages: a possible contributory mechanism for neoplasia in hemochromatosis. Ann $N$ Y Acad Sci 1988, 526:301-309.
27. Bergeron RJ, Streiff RR, Elliot GT: Influence of iron on in vivo proliferation and lethality of $L$ I 2 I 0 cells. J Nutr 1985, I I 5:369-374.

28. Koeken A, Cobbaert C, Quint W, van Doorn LJ: Genotyping of hemochromatosis-associated mutations in the HFE gene by PCR-RFLP and a novel reverse hybridization method. Clin Chem Lab Med 2002, 40(2): I 22- 125.

29. Merryweather-Clarke AT, Pointon JJ, Shearman JD, Robson KJ: Global prevalence of putative haemochromatosis mutations. J Med Genet 1997, 34:275-278.

30. Bozkaya H, Bektas M, Metin O, Erkan O, Ibrahimoglu D, Dalva K, Akbiyik F, Gurel S, Bozdayi AM, Akay C, Yurdaydin C, Aslan O, Uzunalimoglu O: Screening for hemochromatosis in Turkey. Dig Dis Sci 2004, 49:444-449.

3I. Simsek H, Sumer H, Yilmaz E, Balaban YH, Ozcebe O, Hascelik G, Buyukask Y, Tatar G: Frequency of HFE mutations among Turkish blood donors according to transferrin saturation: genotype screening for hereditary hemochromatosis among voluntary blood donors in Turkey. I Clin Gastroenterol 2004, 38:67I-675

32. Liehr JG, Jones JS.: Role of iron in estrogen-induced cancer. Curr Med Chem 2001, 8:839-849.

33. Malins DC, Polissar NL, Gunselman SJ: Progression of human breast cancer to the metastatic state is linked to hydroxyl radical-induced DNA damage. Proc Natl Acad Sci USA 1996, 93:2557-2563.

34. Kondrashova TV, Neriishi K, Ban S, Ivanova TI, Krikunova LI, Shentereva NI, Smirnova IA, Zharikova IA, Konova MV, Taira S, Tsyb AF: Frequency of hemochromatosis gene (HFE) mutations in Russian healthy women and patients with estrogen-dependent cancers. Biochim Biophys Acta 2005, I 762(1):59-65.

35. Syrjakoski KFH, Ikonen T, Kuukasjarvi T, Autio V, Matikainen MP, Tammela TLJ, Koivisto PA, Schleutker J: Hemochromatosis gene mutations among Finnish male breast and prostate cancer patients. Int / Cancer 2006, I | 8:5 I8-520.

36. Adams PC, Reboussin DM, Barton JC, McLaren CE, Eckfeldt JH, McLaren GD, Dawkins FW, Acton RT, Harris EL, Gordeuk VR, Leiendecker-Foster C, Speechley M, Snively BM, Holup JL, Thomson E, Sholinsky P: Hemochromatosis and iron-overload screening in a racially diverse population. $N$ Engl J Med 2005, 352: I 769- I 778

37. Martinez di Montemuros F, Tavazzi D, Salsano E, Piepoli T, Pollo B, Fiorelli G, Finocchiaro G: High frequency of the H63D mutation of the hemochromatosis gene (HFE) in malignant gliomas. Neurology 200I, 57:1342.

38. Tomatsu S, Orii KO, Fleming RE, Holden CC, Waheed A, Britton RS, Gutierrez MA, Velez-Castrillon S, Bacon BR, Sly WS: Contribution of the H63D mutation in HFE to murine hereditary hemochromatosis. Proc Natl Acad Sci USA 2003, 100:15788-15793.

39. Whitfield JB, Cullen LM, Jazwinska EC, Powell LW, Heath AC, Zhu G, Duffy DL, Martin NG: Effects of HFE C282Y and H63D polymorphisms and polygenic background on iron stores in a large community sample of twins. Am J Hum Genet 2000, 66:1246-1258.

40. Beutler E, Felitti V], Koziol JA, Ho NJ, Gelbart T: Penetrance of 845G-.> A (C282Y) HFE hereditary haemochromatosis mutation in the USA. Lancet 2002, 359:2 $11-218$.

4I. Jackson H, Carter K, Darke C, Guttridge MG, Ravine D, Hutton RD Napier JA, Worwood M: HFE mutations, iron deficiency and overload in 10,500 blood donors. $B r$ । Haematol 200I, I | 4:474-484.

42. Burke W, Imperatore G, McDonnell SM, Baron RC, Khoury MJ: Contribution of different HFE genotypes to iron overload disease: a pooled analysis. Genet Med 2000, 2:27I-277.

43. Porto G, Alves H, Rodrigues P, Cabeda JM, Portal C, Ruivo A, Justica $B$, Wolff R, de Sousa M: Major histocompatibility complex class I associations in iron overload: evidence for a new link between the HFE H63D mutation, HLA-A29, and non-classical forms of hemochromatosis. Immunogenetics 1998 47:404-4I0.

44. Cardoso CS, Alves H, Mascarenhas M, Goncalves R, Oliveira P, Rodrigues $P$, Cruz E, de Sousa M, Porto G: Co-selection of the H63D mutation and the HLA-29 allele: a new paradigm of linkage disequilibrium? Immunogenetics 2002, 53:1002-1008.

45. de Jong M, Nolte IM, de Vries EGE, Schaapveld M, Kleibeuker JH, Oosterom E, Oosterwijk JC, van der Hout AH, van der Steege G, Bruinenberg M, Boezen HM, Te Meerman G], van der Graaf WT: The 
HLA class III subregion is responsible for an increased breast cancer risk. Hum Mol Gen 2003, I 2:23 I I-23 I9.

46. Cruz E, Vieira J, Gonçalves R, Alves H, Almeida S, Rodrigues P, Lacerda R, Porto G: Involvement of the Major Histocompatibility Complex region in the genetic regulation of circulating CD8+ T-cell numbers in humans. Tissue Antigens 2004, 64:25-34.

\section{Pre-publication history}

The pre-publication history for this paper can be accessed here:

http://www.biomedcentral.com/1471-2407/6/37/prepub

Publish with Bio Med Central and every scientist can read your work free of charge

"BioMed Central will be the most significant development for disseminating the results of biomedical research in our lifetime. "

Sir Paul Nurse, Cancer Research UK

Your research papers will be:

- available free of charge to the entire biomedical community

- peer reviewed and published immediately upon acceptance

- cited in PubMed and archived on PubMed Central

- yours - you keep the copyright

Submit your manuscript here:

http://www.biomedcentral.com/info/publishing_adv.asp 